\title{
Identifikasi Plat Nomor Kendaraan dengan Metode Optical Character Recognition Menggunakan Raspberry Pi
}

\author{
Winarno Sugeng ${ }^{1}$, Rio Korio $\mathrm{U}^{2}$, Mochamad Tegar $\mathrm{P}^{3}$ \\ 1,2,3 Jurusan Informatika, Fakultas Teknologi Industri, Institut Teknologi Nasional, Bandung \\ J.PH.H. Mustofa No.23 Bandung 40124, Indonesia. \\ e-mail:, ${ }^{1}$ winarno@itenas.ac.id, ${ }^{2}$ korio.utoro@itenas.ac.id, ${ }^{3}$ tegarmochamad@gmail.com
}

\begin{abstract}
Abstrak
Plat Nomor Kendaraan merupakan identitas bagi setiap kendaraan bermotor yang terdaftar oleh pemerintah Indonesia. Proses identifikasi plat nomor diawali dengan pembambilan gambar kendaraan dengan kamera. Gambar akan di resize untuk menyamakan ukuran citra dan crop untuk memisahkan antara plat nomor dengan bagian kendaraan lainnya menggunakan algoritma Perspective Transform, setelah itu di crop kembali untuk memisahkan antara kode wilayah, kode registrasi dan kode seri wilayah, lalu setiap karakter akan dikenali menggunakan metode Optical Character Recognition (OCR) berdasarkan citra karakter hasil crop. Terdapat proses character error handling untuk meningkatkan tingkat akurasi identifikasi pada karakter plat nomor. Plat nomor Indonesia yang diujikan terbagi menjadi 4 kategori yaitu Plat Standar Mobil, Plat Kustom Mobil, Plat Tidak Standar dan Plat Motor. Resolusi kamera terbaik menggunakan resolusi $1280 \times 720$ piksel dan menghasilkan rata-rata waktu uji 6,51 detik. Persentase kebenaran identifikasi karakter terbesar untuk plat standar sebesar $100 \%$ pada nilai lux 20 39 dan nilai lux 70 99, sedangkan untuk plat nomor kustom persentase kebenaran identifikasi karakter terbesar sebesar 58\% pada nilai lux 90 140. Sedangkan untuk plat tidak standar tidak ada persentase kebenaran identifikasi karakter terbesar menghasilkan persentase $0 \%$ pada semua nilai lux yang diujikan. Untuk plat nomor motor persentase kebenaran identifikasi karakter terbesar sebesar $8 \%$ pada nilai lux 150 199. Sehingga dapat ditarik kesimpulan bahwa plat nomor standar menjadi rekomendasi yang tepat bagi setiap kendaraan bermotor yang ada di Indonesia.
\end{abstract}

Kata Kunci: Komputer Mini, Plat Kendaraan, OCR.

\begin{abstract}
Vehicle Number Plate is the identity of each vehicle registered by the Indonesian government. The process of collecting license plates begins with shooting a vehicle with a camera. The image will be resized to match the image size and cut to number plates with other vehicle parts using the Transformation Perspective algorithm, after that cut back to make it easier for the area code, registration code and area serial code, then each character will be recognized using the Optical Character Recognition method (OCR) based on the image of the crop character. Obtained incorrect handling of characters to increase the agreed level on number plate characters. The Indonesian number plates tested are divided into 4 categories namely Car Standard Plates, Custom Car Plates, Nonstandard Plates and Motorcycle Plates. The camera resolution is $1280 \times 720$ pixels and the average resolution is 6.51 seconds. The largest average truth value for standard plates is 100\% for lux values $20 \sim 39$ and lux values are $70 \sim 99$, while for custom plates the largest average truth value is $58 \%$ at lux values $90 \sim 140$. Whereas for nonstandard plates no some have character percentages, get $0 \%$ on all tested lux values. For motorcycle number plates the percentage of the right to determine the largest character of $8 \%$ at a value of $150 \sim 199$ lux. Can be drawn conclusion that the standard number plate be an appropriate recommendation for each vehicle in Indonesia.
\end{abstract}

Keywords: Mini Computer, Vehicle License, OCR. 


\section{Pendahuluan}

TNKB sebuah kendaraan terdiri dari baris pertama yang terdiri dari huruf untuk menunjukkan kode wilayah, biasanya merupakan area keresidenan, sebuah wilayah administratif yang terdiri dari beberapa kabupaten, kemudian di ikuti bagian kedua berupa angka yang menunjukkan nomor polisi kendaraan dan bagian ketiga adalah huruf yang menunjukkan kabupaten domisili pemilik kendaraan dan baris kedua menunjukkan bulan dan tahun masa berlaku TNKB. TNKB harus diperbaharui dalam masa 5 tahun sekali (Budianto, Adji, \& Hartanto, 2015). TNKB atau plat nomor kendaraan menjadi identitas ketika memasuki lokasi parkir berdasarkan sistem parkir yang digunakan. Sedangkan sistem parkir merupakan lahan untuk kendaraan tidak bergerak yang tidak bersifat sementara waktu (Buana \& Sukirman, 2016).

Terdapat perbandingan yang perlu dilakukan untuk menentukan metode terbaik yang digunakan dengan kandidat Haar Transform dan Neural Network dan Optical Character Recognition (OCR). (Ghorpade \& Katkar, 2014) melakukan penelitian untuk mempelajari algoritma Haar Transform dan Backpropagation Neural Network dengan studi kasus kompresi image, dan penelitian tersebut menghasilkan pernyataan metode Haar Transform dan Backprogaration Neural Network cocok untuk kompresi image dikarenakan menghasilkan image yang memiliki ukuran file kecil tetapi kekurangannya gambar tersebut menjadi pecah pikselnya sehingga untuk studi kasus penelitian ini tidak cocok diterapkan. (Phangtriastu, Harefa, \& Tanoto, 2017) melakukan penelitian untuk membanding algoritma Neural Network dengan Support Vector Machine (SVM) menggunakan metode Optical Character Recognition (OCR), dan penelitian ini menghasilkan bahwa metode SVM tidak cocok untuk OCR sehingga diberikan opsi dengan penggabungan antara OCR dan Template Matching dan menghasilkan tingkat akurasi lebih dari $90 \%$. Sehingga metode OCR menjadi landasan yang kuat dalam implementasi pada kasus ini.

Oleh sebab itu sebuah penelitian identifikasi plat nomor kendaraan bermotor dengan standar Republik Indonesia dilakukan dengan memanfaatkan teknologi Raspberry Pi. Raspberry Pi adalah komputer berukuran kecil sebesar kartu kredit dan memiliki fungsi serupa dengan komputer pada umumnya (Tauchid, Rumani, \& Irawan, 2015). Penelitian ini fokus pada identifikasi plat nomor kendaraan bermotor dengan standar Republik Indonesia dengan studi kasus sistem parkir Itenas Bandung (Buana \& Sukirman, 2016). Penelitian ini menggunakan perangkat Raspberry $P i$ dan Camera serta menggunakan Algoritma cropping Perspective Transform untuk memisahkan antara objek plat nomor dengan objek lain selain plat nomor kendaraan (Hartanto, Sugiharto, \& Endah, 2015), setelah itu, proses selanjutnya pengenalan karakter menggunakan metode Optical Character Recognition (OCR) dan setelahnya akan ada proses character error handling untuk meningkatkan akurasi identifikasi karakter pada plat nomor.

Sistem parkir pada umumnya memiliki permasalahan yang terjadi karena adanya kelemahan dari pencatatan nomor polisi secara manual, yaitu adanya kemungkinan kesalahan penulisan nomor polisi yang disebabkan oleh faktor kesalahan manusia (human error), dan lamanya proses pencatatan nomor polisi oleh petugas (Bahtiar, 2016). Dengan hal ini maka akan didapatkan solusi yaitu berupa suatu sistem parkir yang memiliki sistem identifikasi plat nomor untuk mengatasi permasalahan pencatatan nomor polisi secara manual serta kemungkinan kesalahan penulisan plat nomor dan waktu antri dalam identifikasi plat nomor kendaraan bermotor di Indonesia (Pemayun, Setiawan, \& ER, 2015). Dengan lebih spesifik permasalahan yang ada di Itenas Bandung, tidak diperbolehkannya mahasiswa angkatan baru untuk membawa kendaraan mobil, berarti akan dibuatkan sistem parkir dengan dasar penelitian identifikasi plat nomor kendaraan. Dimana saat kendaraan masuk area pintu parkir maka akan ada identifikasi plat nomor kendaraan, setelah melalui tahapan identifikasi maka plat nomor muncul dalam bentuk teks, teks tersebut akan dicocokan dengan data di database pemilik kendaraan di Itenas. Saat teks plat nomor cocok dengan data kepemilikan kendaraan yang terdaftar di Itenas, maka pintu parkir terbuk dant tanda lampu LED berwarna hijau (sistem berjalan sesuai dengan perancangan). Jika pemilik kendaraan adalah mahasiswa angkatan baru maka akan ada peringatan tidak boleh masuk oleh petugas parkir berdasarkan tanda lampu 
LED yang terpasang di pintu parkir (merah artinya mobil merupakan mahasiswa baru) dan pintu parkir pun tidak terbuka. Selain sistem yang dibuat untuk penelitian tersebut dibuatkan juga 1(satu) sistem monitoring yang berfungsi untuk mengawasi jalannya sistem tersebut. Parameter yang diawasi yaitu jumlah kendaraan yang teridentifikasi dan tidak selain itu waktu identifikasi sehingga data tersebut dapat dijadikan parameter pengujian. Sistem monitoring ini pun memiliki beberapa fungsi lain yaitu sebagai sarana untuk registrasi pengguna kendaraan bermotor, selain itu bagi pengguna dapat melihat riwayat selama parkir di Itenas. Jika sebagai administrator dapat melihat riwayat parkir, daftar pengguna dan parameter yang diawasi pada sistem ini. Sistem ini dibangun menggunakan platform Android dikarenakan mayoritas pengguna smartphone di Indonesia menggunakan platform Android.

\section{Metode Penelitian}

Pada metode penelitian berikut ini akan membahas tentang analisis proses sistem, blok diagram dan flowchart sistem.

\section{Analisis Proses Sistem}

Cara kerja sistem secara keseluruhan dapat dilihat pada Gambar 1. Terdapat beberapa langkah dalam identifikasi plat nomor kendaraan.

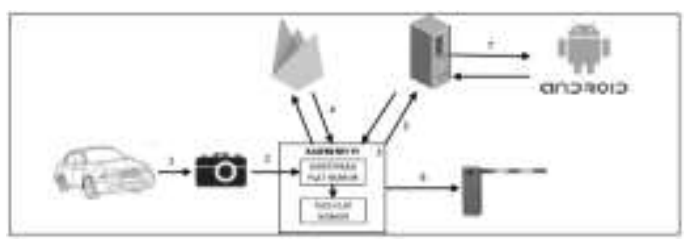

Gambar 1. Prinsip Kerja Sistem

Terdapat tujuh proses dalam menyelesaikan sistem.

1. Kamera mengambil gambar dari sebuah mobil.

2. Gambar dikirim ke Raspberry Pi untuk diidentifikasi plat nomor yang digunakan oleh mobil tersebut.

3. Optical Character Recognition (OCR) merupakan sebuah seni mendeteksi, membagi dan mengenali huruf dari suatu citra. Lebih tepatnya, OCR adalah sebuah proses pendeteksian dan pengenala huruf dari sebuah citra dan mengubahnya menjadi kode American Standard Code for Information Interchange $(A S C I)$ atau bentuk lainya yang dapat dimengerti oleh komputer/mesin (Rao,
A.S.N.Chakravarthy, A.S.C.S.Sastry, \& $P, \quad 2016)$. Proses identifkasi menggunakan metode Optical Character Recognition (OCR) untuk identifikasi karakter setiap plat nomor. Setelah diidentifikasi, maka akan menghasilkan teks plat nomor.

4. Setelah mendapatkan teks hasil identifikasi gambar dari kamera dikirim ke firebase untuk nantinya disimpan dalam firebase storage, dari firebase mengembalikan alamat uri gambar.

5. Alamat uri dan teks plat nomor dikirim ke server melalui API yang telah dibuat di server, setelah itu API server akan mengembalikan nilai berupa status keberhasilan, yaitu transaksi sukses atau gagal.

6. Setelah diterima oleh Raspberry Pi status yang diberikan oleh API server maka Raspberry Pi akan membuka pintu parkir.

7. Sistem akan diawasi oleh Android dengan berdasarkan data yang diterima dari API server.

\section{Blok Diagram}

Blok diagram dari sistem yang akan dibangun dapat dilihat pada Gambar 2 berikut:

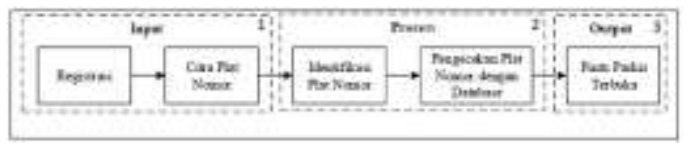

Gambar 2. Blok Diagram Sistem

Pada Gambar 2, ditunjukkan blok diagram pada proses identifikasi plat nomor kendaraan dengan menggunakan metode OCR. Selanjutnya akan dijelaskan mengenai skema perangkat yang terhubung pada sistem yang telah dibuat berdasarkan boundering yang telah ditandai sebagai berikut:

1. Input berupa testing image. Testing image digunakan untuk tahapan proses dimana datanya pun merupakan citra gambar kendaraan mobil.

2. Process terdiri dari tahapan preprocessing, Optical Character Recognition (OCR) dan character error handling. Tahapan pre-processing terdiri crop dan resizing. OCR digunakan sebagai metode yang berfungsi mengubah citra karakter menjadi teks karakter sehingga dapat diproses pada character error handling yang berfungsi untuk menyaring (filtering) karakter yang teridentifikasi sehingga sama dengan 
karakter plat nomor itu sendiri. Dikarenakan metode OCR memiliki tingkat akurasi pembacaan kurang baik disebabkan faktor cahaya pada plat nomor dalam proses identifikasi setiap karakter yang ada pada plat nomor maka dari itu harus dilakukan proses penyaringan (filtering) karakter agar hasil identifikasi setiap karakter sesuai dengan karakter yang ada di plat nomor.

3. Output berupa teks hasil identifikasi plat nomor kendaraan.

\section{Flowchart}

Flowchart adalah adalah suatu bagan dengan simbol-simbol tertentu yang menggambarkan urutan proses secara mendetail dan hubungan antara suatu proses (instruksi) dengan proses lainnya dalam suatu program.

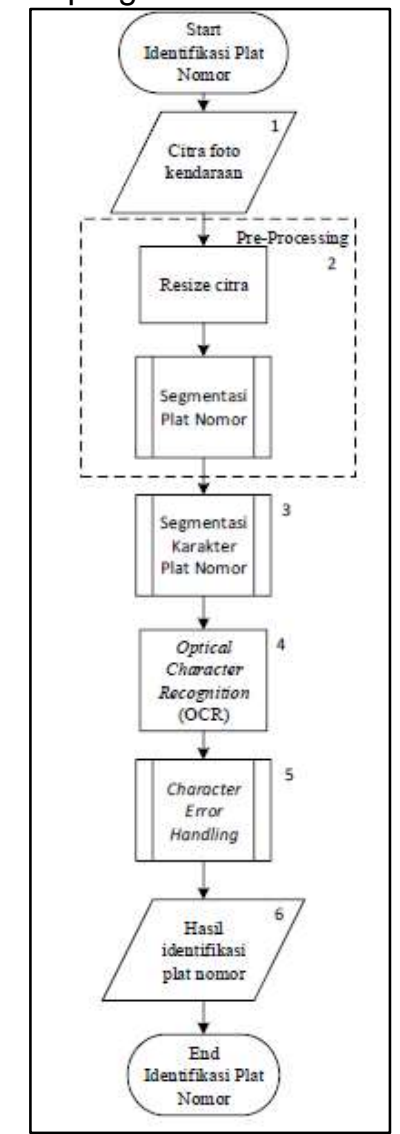

Gambar 3. Flowchart Sistem

Berdasarkan Gambar 3 dijelaskan mengenai alur proses identifikasi citra plat nomor berikut ini:

1. Citra foto kendaraan diambil menggunakan kamera.

2. Pre-processing terdiri dari resize citra dan juga bagian proses segmentasi plat nomor kendaraan.
3. Segmentasi karakter plat nomor dilakukan untuk memisahkan antara bagian kode wilayah, kode registrasi dan kode seri wilayah.

4. Optical Character Recognition (OCR) dilakukan untuk mengenali setiap karakter citra dan mengubahnya ke teks.

5. Hasil OCR dari point 4 akan diproses kembali dengan character error handling untuk meningkatkan tingkat akurasi identifikasi nomor polisi.

6. Setelah proses identifikasi akan keluar hasil identifikasi plat nomor berupa teks yang nantinya akan dikirim ke server melalui $A P I$.

Flowchart Segmentasi Plat Nomor

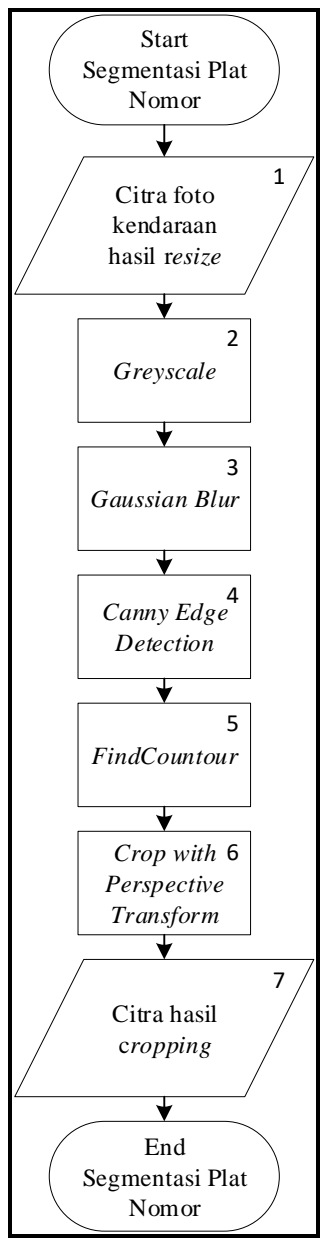

Gambar 4. Flowchart Segmentasi Plat Nomor

Berdasarkan Gambar 4, dijelaskan mengenai alur proses segmentasi plat nomor kendaraan berikut ini:

1. Input berbentuk citra hasil resize.

2. Greyscale mengubah citra RGB menjadi keabuan (gray). 
3. Gaussian blur untuk menghilangkan noise yang ada pada citra.

4. Canny edge detection untuk melihat tepi dari setiap plat nomor sehingga dapat mempermudah untuk proses crop.

5. FindContour untuk membuat Outline sehingga terlihat bagian mana yang akan di crop.

6. Perspective Transform untuk mengambil citra hasil outline.

7. Setelah melalui proses dari point 1-6 maka akan menghasilkan citra hasil crop.

Flowchart Segmentasi Karakter Plat Nomor

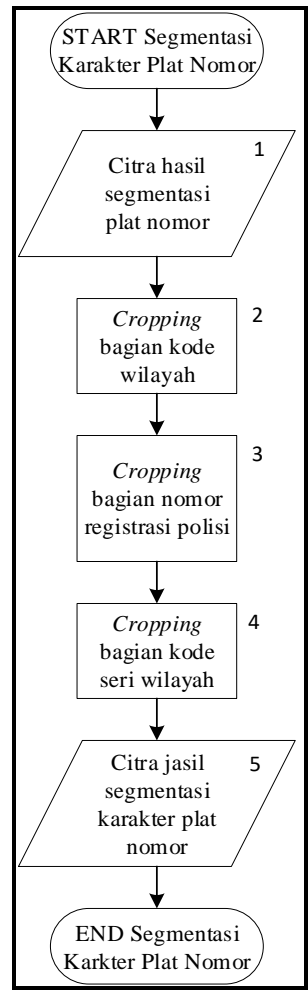

Gambar 5. Flowchart Segmentasi Karakter Plat Nomor

Berdasarkan Gambar 5, dijelaskan alur kerja segmentasi karakter plat nomor berikut ini:

1. Input berbentuk citra hasil segmentasi plat nomor.

2. Cropping untuk mengambil bagian kode wilayah dari plat nomor.

3. Cropping untuk mengambil bagian kode registrasi polisi dari plat nomor.

4. Cropping untuk mengambil bagian kode seri wilayah dari plat nomor.

5. Citra hasil segmentasi per bagian pada plat nomor kendaraan.

Flowchart Character Error Handling

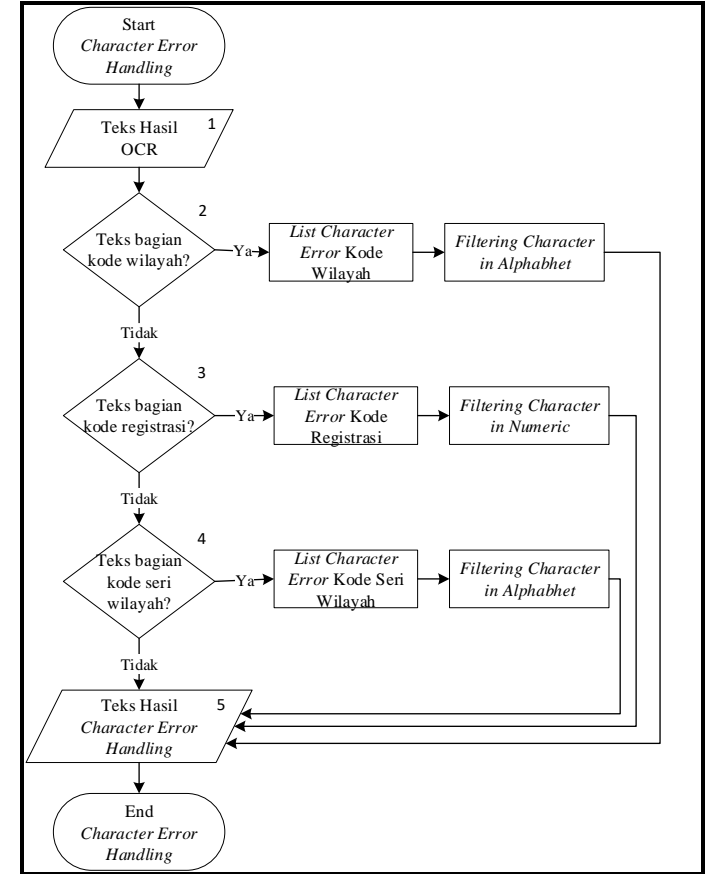

Gambar 6. Flowchart Character Error Handling

Berdasarkan Gambar 6, dijelaskan alur proses character error handling berikut ini:

1. Input berbentuk teks hasil OCR pada proses sebelumnya.

2. Jika teks bagian kode wilayah maka akan ada karakter yang biasa error pada proses OCR, setelah itu di filter berdasarkan alphabet untuk setiap karakter.

3. Jika teks bagian kode registrasi maka akan ada karakter yang biasa error pada proses OCR, setelah itu di filter berdasarkan numeric untuk setiap karakter.

4. Jika teks bagian kode seri wilayah maka akan ada karakter yang biasa error pada proses OCR, setelah itu di filter berdasarkan alphabet untuk setiap karakter.

5. Setiap karakter yang telah di handling maka akan digabungkan dan dijadikan 1 teks kembali.

\section{Hasil dan Pembahasan}

Pengujian Sistem

Pengujian dilakukan dengan 2 tahap yaitu pengujian Alpha dan Beta.

\subsection{Pengujian Alpha}

Pada pengujian alpha dilakukan pengujian pada sistem identifikasi plat nomor kendaraan di raspberry pi. Pengujian 
dilakukan bertahap dari mulai pengambilan gambar oleh kamera hingga proses identifikasi nomor polisi oleh metode OCR dan diproses setiap karakternya oleh character error handling untuk meningkatkan akurasi kebenaran identifikasi plat nomor.

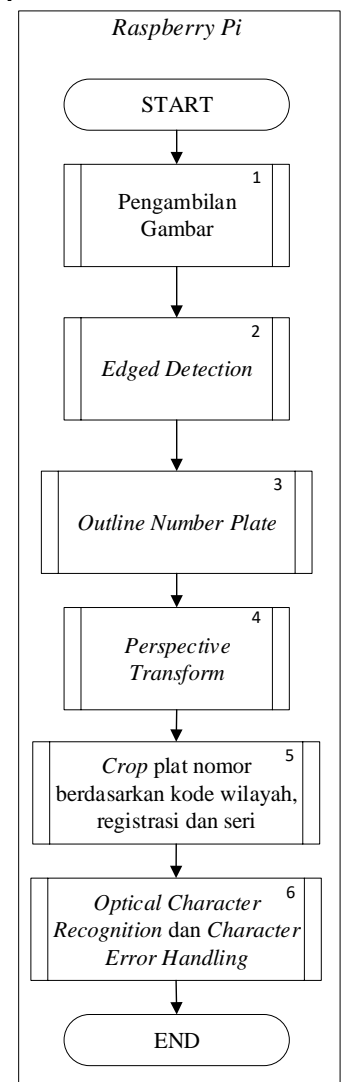

Gambar 7. Skenario Pengujian Alpha

Berdasarkan Gambar 7, dijelaskan alur pengujian alpha pada point-point berikut ini:

1. Pengambilan gambar oleh kamera.

2. Setelah itu, gambar diproses preprocessing dengan edged detection canny untuk mencari garis tepi dari objek sehingga dapat terlihat bentukan persegi panjang dari plat nomor.

3. Setelah terlihat akan dibentuk garis persegi panjang pada objek plat nomor.

4. Setelah terdapat garis (outline) maka akan di crop oleh perspective transform berdasarkan garis yang telah dibentuk.

5. Citra hasil perspective transform akan di crop menjadi 3 bagian dari plat nomor yaitu kode wilayah, kode registrasi dan kode seri wilayah untuk memudah proses identifikasi dari setiap karakter plat nomor.

6. Proses identifikasi dilakukan menggunakan metode optical character recognition (OCR) dan hasilnya akan diproses kembali oleh character error handling untuk meningkatkan kebenaran hasil identifikasi plat nomor kendaraan.

Pengambilan Gambar

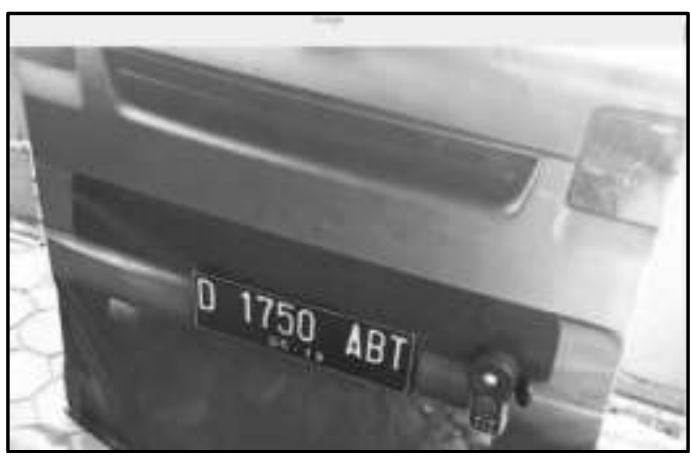

Gambar 8. Hasil Pengambilan Gambar

Pengujian ini dilakukan dengan cara Raspberry pi mengambil gambar mobil menggunakan kamera.

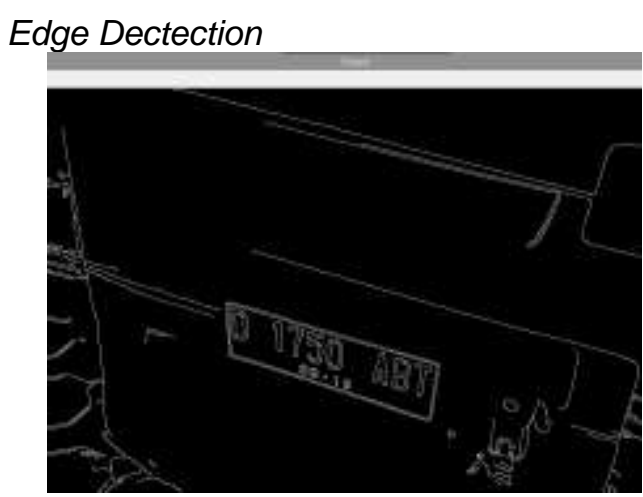

Gambar 9. Hasil Edge Detection

Pengujian ini menghasilkan citra hasil pengambilan gambar oleh kamera diolah dengan menggunakan pre-processing edged canny detection untuk mendapatkan garis tepi dari setiap objek pada citra.

\section{Outline Plat Nomor}

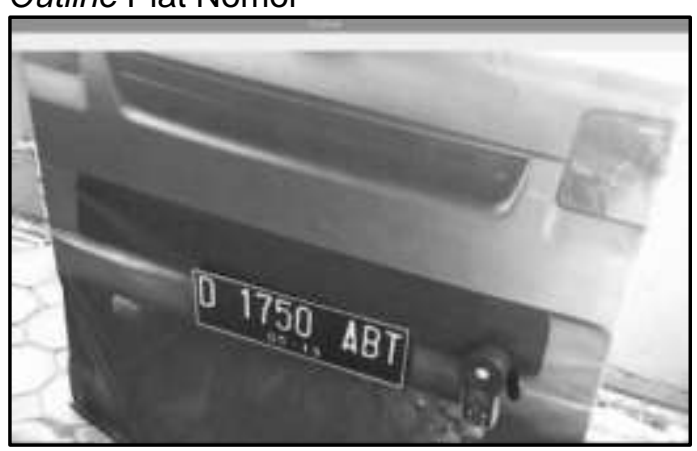

Gambar 10. Hasil Outline Plat Nomor

Pengujian ini menghasilkan citra hasil pre-processing digunakan untuk membuat 
outline berdasarkan 4 sudut yang terbentuk sehingga membuat bidang persegi panjang. Perspective Transform

1.1.1.1.

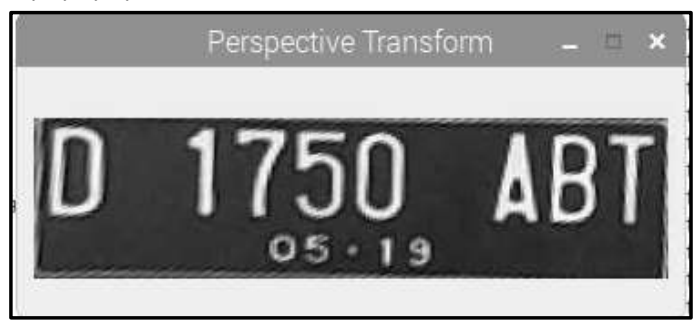

Gambar 11. Hasil Perspective Transform

Pengujian ini menghasilkan citra hasil outline merupakan dasar dari crop perspective transform. Plat nomor telah dipisahkan dari bagian lain pada mobil.

Crop plat berdasarkan kode wilayah, registrasi dan seri

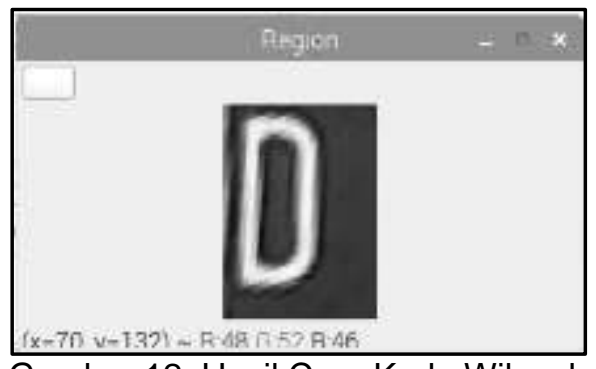

Gambar 12. Hasil Crop Kode Wilayah

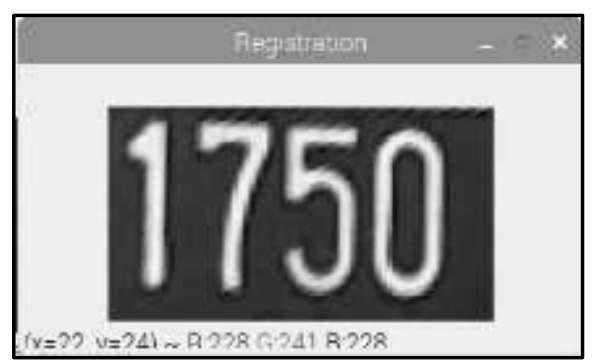

Gambar 13. Hasil Crop Kode Registrasi

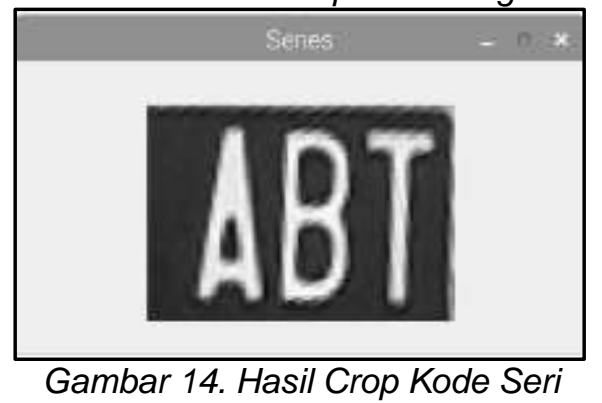

Pengujian ini menghasilkan crop plat nomor menjadi bagian kode wilayah, kode registrasi dan kode seri wilayah sehingga mempermudah proses identifikasi plat nomor kendaraan dan meningkatnya tingkat kebenaran identifikasi karakter plat nomor.

\section{Character Error Handling}

PLATE DETECTION
Before Filter Region : \{D
After Filter Region : D
Before Filter Registration : $1750^{\prime}$
After Filter Registration : 1750
Before Filter Series : ABT\}
After Filter Series : ABT
FINAL PLATE : D 1750 ABT

Gambar 15. Hasil Character Error Handling

Pengujian ini menghasilkan citra crop teridentifkasi per bagian yaitu region (wilayah), registration (registrasi) dan series (seri). Pada hasil pun terlihat bahwa character error handling pun berfungsi dengan baik sehingga hasil identifikasi adalah benar yaitu D 1750 ABT.

\section{Pengujian Beta}

Pada pengujian beta merupakan pengujian penggunaan implementasi yang dilakukan oleh pengguna pada tempat terbuka dengan sinar cahaya matahari yang terang dengan situasi yang dibuat berdasarkan studi kasus parkir yang ada di Itenas. Pengujian beta dilakukan dengan berdasarkan pada beberapa parameter antara lain cahaya, waktu uji, resolusi kamera dan penggunaan casing acrylic pada plat nomor.

Pengujian beta dilakukan dengan membuat kategori plat nomor kendaraan yaitu plat nomor standar, plat nomor kustom, plat nomor tidak standar dan plat nomor motor. Sehingga kemampuan sistem dapat diukur untuk setiap kategorinya dan berdasarkan pengujian beta yang dilakukan.

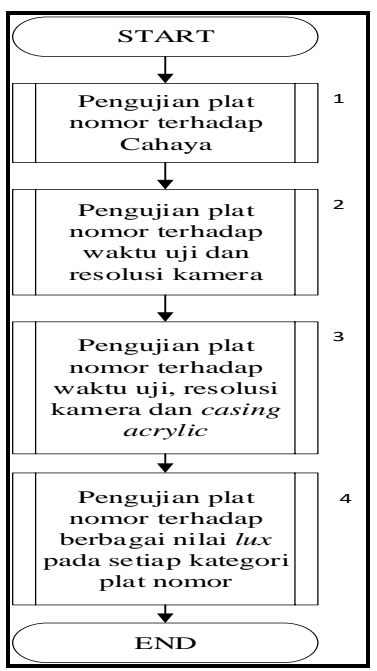

Gambar 16. Skenario Pengujian Beta 
Berdasarkan Gambar 16, dijelaskan bahwa pengujian yang dilakukan memiliki parameter cahaya, waktu uji, resolusi kamera dan casing acrylic yang dijelaskan pada pointer-pointer berikut ini:

1. Pengujian plat nomor terhadap cahaya dilakukan untuk mencari cahaya uji terbaik sehingga dapat diterapkan pada parameter pengujian lainnya.

2. Pengujian plat nomor terhadap waktu uji dan resolusi kamera yang berbeda-beda dilakukan untuk mengetahui kemampuan sistem dalam identifikasi plat nomor kendaraan berdasarkan nilai cahaya uji terbaik yang dilakukan pada pengujian cahaya sebelumnya.

3. Pengujian plat nomor terhadap waktu uji, resolusi kamera dan casing acrylic dilakukan untuk mengetahui apakah sistem dapat berfungsi jika plat nomor ditutupi oleh casing acrylic dan juga pengujian dilakukan dengan menggunakan resolusi kamera yang berbeda-beda untuk menguji kehandalan sistem.

4. Pengujian plat nomor terhadap berbagai nilai lux pada setiap kategori plat nomor dilakukan untuk mengetahui apakah sistem dapat mengidentifikasi plat nomor dengan kategori yang berbeda dan dengan nilai lux yang berbeda juga.

\subsubsection{Pengujian plat nomor terhadap Cahaya}

Tabel 1. Hasil pengujian terhadap Cahaya

\begin{tabular}{|l|}
\hline \multicolumn{1}{|c|}{ HASIL PENGUJIAN } \\
\hline $0-50$ Lux: 40\% \\
$50-100$ Lux: $60 \%$ \\
$100-150$ Lux: $100 \%$ \\
$150-210$ Lux: 0\% \\
\hline \multicolumn{1}{|c|}{ KESIMPULAN } \\
\hline Berdasarkan hasil pengujian yang telah \\
dilakukan, dapat disimpulkan bahwa \\
sistem dapat mengidentifikasi plat nomor \\
pada nilai lux 20 189. Tetapi untuk hasil \\
identifikasi plat nomor yang benar \\
terdapat pada nilai lux 20 39 dan nilai lux \\
$70 \sim 149$. \\
\hline
\end{tabular}

\subsubsection{Pengujian plat nomor terhadap waktu uji dan resolusi kamera}

Tabel 2. Hasil pengujian terhadap waktu dan resolusi kamera

\begin{tabular}{|c|}
\hline HASIL PENGUJIAN \\
\hline 1920x1080 piksel: $90 \%$ \\
1280x720 piksel: $100 \%$ \\
\hline
\end{tabular}

\begin{tabular}{|l|}
\hline $640 \times 480$ piksel: $0 \%$ \\
\hline KESIMPULAN \\
\hline Berdasarkan hasil pengujian yang telah \\
dilakukan, dapat disimpulkan bahwa \\
persentase kebenaran identifikasi plat \\
nomor pada plat nomor dengan resolusi \\
kamera $640 \times 480$ piksel sebesar $0 \%$ \\
dengan rata-rata waktu uji 4,09 detik, \\
untuk persentase kebenaran resolusi \\
kamera 1280x720 piksel sebesar $100 \%$ \\
dengan rata-rata waktu uji 6,51 detik dan \\
untuk persentase kebenaran resolusi \\
kamera 1920x1080 piksel sebesar $90 \%$ \\
dengan rata-rata waktu uji 6,51 detik. \\
Sehingga untuk persentase tingkat \\
kebenaran terbesar terdapat pada \\
resolusi kamera $1280 \times 720$ piksel, tetapi \\
untuk waktu uji tercepat terdapat pada \\
resolusi kamera $640 \times 480$ piksel hal ini \\
dikarenakan plat nomor pada resolusi \\
kamera $640 \times 480$ piksel $80 \%$ tidak \\
teridentifikasi maka sistem tidak akan \\
melakukan proses identifikasi karakter \\
plat nomor yang membutuhkan waktu $2-$ \\
3 detik. \\
\hline
\end{tabular}

\subsubsection{Pengujian plat nomor terhadap waktu uji, resolusi kamera dan casing acrylic \\ Tabel 3. Hasil pengujian terhadap waktu uji,} resolusi kamera dan casing acrylic

\begin{tabular}{|l|}
\hline HASIL PENGUJIAN \\
\hline $1920 \times 1080$ piksel: $80 \%$ \\
$1280 \times 720$ piksel: $90 \%$ \\
$640 \times 480$ piksel: $0 \%$ \\
\hline \multicolumn{2}{|c|}{ KESIMPULAN } \\
\hline Berdasarkan hasil pengujian yang telah \\
dilakukan dapat disimpulkan bahwa \\
persentase kebenaran identifikasi plat \\
nomor pada plat nomor dengan resolusi \\
kamera $640 \times 480$ piksel sebesar $0 \%$ \\
dengan rata-rata waktu uji 3,81 detik, \\
untuk persentase kebenaran resolusi \\
kamera 1280x720 piksel sebesar $90 \%$ \\
dengan rata-rata waktu uji 6,51 detik dan \\
untuk persentase kebenaran resolusi \\
kamera 1920x1080 piksel sebesar $80 \%$ \\
dengan rata-rata \\
\hline
\end{tabular}

\subsubsection{Pengujian plat nomor terhadap berbagi nilai lux pada setiap kategori plat nomor}

Tabel 4. Hasil pengujian terhadap nilai lux di setiap kategori plat nomor

HASIL PENGUJIAN

Plat Nomor Standar: $100 \%$, lux 20-39 dan lux 70-99 


\begin{tabular}{|l|}
\hline Plat Nomor Kustom: 58\%, lux 90-140 \\
Plat Nomor Tidak Standar: 0\% \\
\hline \multicolumn{3}{|c|}{ KESIMPULAN } \\
\hline Berdasarkan hasil pengujian yang telah \\
dilakukan, dapat disimpulkan bahwa \\
persentase kebenaran terbesar untuk plat \\
standar sebesar 100\% pada nilai lux \\
$20 \sim 39$ dan nilai lux $70 \sim 99$, sedangkan \\
untuk plat nomor kustom persentase \\
kebenaran terbesar sebesar 58\% pada \\
nilai lux 90 140. Sedangkan untuk plat \\
tidak standar tidak ada persentase \\
kebenaran terbesar dikarenakan \\
menghasilkan persentase 0\% pada \\
semua nilai lux yang diujikan. Untuk plat \\
nomor motor persentase kebenaran \\
terbesar sebesar 8\% pada nilai lux \\
$150 \sim 199 . \quad$ a \\
\hline
\end{tabular}

\subsection{Grafik Hasil Pengujian}

Grafik pengujian digunakan untuk merepresentasikan hasil pengujian dalam bentuk grafik batang sehingga dapat dipahami secara menyeluruh.

$$
\begin{aligned}
& \text { Persentase Pengujian Lux }
\end{aligned}
$$

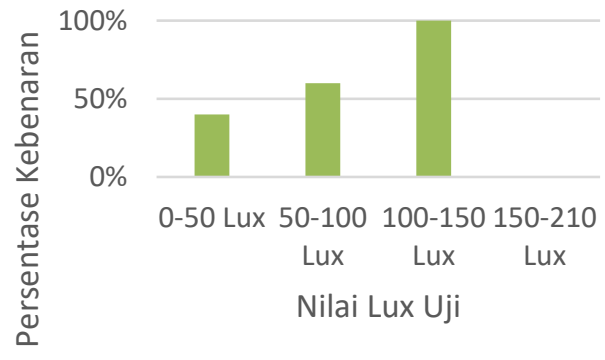

\section{Gambar 17. Grafik hasil pengujian lux}

\section{Kesimpulan}

Berdasarkan tujuan dari penelitian dimana sistem identifikasi plat nomor kendaraan bermotor menggunakan Raspberry $\mathrm{Pi}$ telah dilakukan pengujian berdasarkan parameter cahaya dan waktu uji dengan berdasarkan pada angle, jarak dan tinggi kamera dari parkir Itenas Bandung. Berdasarkan pengujian nilai lux terbaik yang telah dilakukan disimpulkan nilai lux terbaik terdapat pada 100 150 lux. Sedangkan berdasarkan pengujian terhadap resolusi kamera dan waktu uji, persentase kebenaran terbesar terdapat pada resolusi kamera $1280 \times 720$ piksel dengan rata-rata waktu uji 6,51 detik dan untuk pengujian yang berdasarkan pada resolusi kamera dan waktu uji menggunakan casing acrylic persentase kebenaran terbesar terdapat pada resolusi kamera
$1280 \times 720$ piksel dengan rata-rata waktu uji 6,51 detik. Sedangkan untuk pengujian dengan berbagai nilai lux untuk setiap kategori plat nomor kendaraan diuji sebanyak 60 kali, dengan jumlah plat nomor yang diuji sebanyak 12 buah, maka total pengujian yang dilakukan sebanyak 720 kali. Berdasarkan hasil penelitian yang telah dilakukan dapat disimpulkan bahwa sistem identifikasi plat nomor kendaraan menggunakan Raspbery $\mathrm{Pi}$ memiliki persentase kebenaran terbesar untuk plat standar sebesar $100 \%$ pada nilai lux 20 39 dan nilai lux 70 99, sedangkan untuk plat nomor kustom persentase kebenaran terbesar sebesar $58 \%$ pada nilai lux 90 140. Sedangkan untuk plat tidak standar tidak ada persentase kebenaran terbesar dikarenakan menghasilkan persentase 0\% pada semua nilai lux yang diujikan. Untuk plat nomor motor persentase kebenaran terbesar sebesar 8\% pada nilai lux 150 199. Dapat disimpulkan bahwa penggunaan plat nomor standar merupakan rekomendasi dikarenakan mendapat persentase tertinggi daripada kategori plat nomor lainnya. Dan kemampuan sistem akan bekerja dengan optimal jika menggunakan kategori plat nomor standar dengan resolusi kamera $1280 \times 720$ piksel.

\section{Referensi}

Avianto, D. (2016, January). Pengenalan

Pola Karakter Plat Nomor

Kendaraan menggunakan Algoritma Momentum

Backpropagation Neural Network. Jurnal Informatika, 10(1), 11991209.

Bahtiar, A. (2016, December). Sistem Deteksi Nomor Polisi Mobil dengan Menggunakan Metode Haar Classifier dan OCR guna Mempermudah Administrasi Pembayaran Parkir. Jurnal of Informatika and Technology, 4(1), 40-46.

Buana, A. T., \& Sukirman, S. (2016, September). Studi Penggunaan Lahan Parkir Mobil di Kampus Itenas Bandung. Reka Racana Jurnal Online Institut Teknologi Nasional, 2(3), 73-82.

Budianto, A., Adji, T. B., \& Hartanto, R. (2015, Mei). Deteksi Nomor Kendaraan Dengan Metode Connected Component dan SVM. 
Jurnal TIM Darmajaya, 1(1), 106117.

Ghorpade, A., \& Katkar, P. (2014, July). Image Compression Using Haar Transform And Modified Fast Haar Wavelet Transform. International Journal of Scientific and Techonology Research, 3(7), 302305.

Hartanto, S., Sugiharto, A., \& Endah, S. N. (2015). Optical Character Recognition menggunakan Algoritma Template Matching Correlation. Jurnal Masyarakat Informatika, 5(9), 1-11.

Pemayun, A. I., Setiawan, W., \& ER, N. I. (2015, June). Analisis Sistem Pendeteksi Posisi Plat Kendraan dari Citra Kendaraan. E-Journal SPEKTRUM, 2(2), 61-67.

Phangtriastu, M. R., Harefa, J., \& Tanoto, D. F. (2017). Comparison between Neural Network and Support Vector
Machine in Optical Character Recognition. 2nd International Conference on Computer Science and Computational Intelligence 2017. 116, pp. 351-357. Bali: Procedia Computer Science.

Rao, N. V., A.S.N.Chakravarthy, A.S.C.S.Sastry, \& P, C. K. (2016, January 20). Optical Character Recognition Technique. Journal of Theoretical and Applied Information Technology, 83(2), 275-282.

Tauchid, N. A., Rumani, R., \& Irawan, B. (2015, August). Analisis Performansi Metode KNN (KNearest Neighbor) Untuk Pengenalan Karakter pada Plat Nomor Kendaraan di Raspberry Pi. e-Proceeding of Engineering, 2(2), 3575-3581. 